\title{
Analysis of Fragmentation Processes in High-Mountain Forests of the Centre of Mexico
}

\author{
Angel Rolando Endara-Agramont ${ }^{*}$, Rafael Calderón-Contreras ${ }^{2}$, Gabino Nava-Bernal ${ }^{1}$, \\ Sergio Franco-Maass ${ }^{1}$
}

${ }^{1}$ Instituto de Ciencias Agropecuarias y Rurales, Toluca, México; ${ }^{2}$ Universidad Autónoma Metropolitana, D. F. México, México.

Email: "rolandoendara@hotmail.com, arendara@uaemex.mx, georafael@yahoo.com.mx, gnavab@uaemex.mx, sfrancom@uaemex.mx

Received January $8^{\text {th }}, 2013$; revised February $8^{\text {th }}, 2013$; accepted February $16^{\text {th }}, 2013$

\begin{abstract}
High-mountain forests ( $>3500$ masl) are the main supplier of environmental services to Mexico City and its metropolitan area. Taking as a study case the Nevado de Toluca National Park, this article focuses on the considerable reduction on the density of its forest cover, characterised by disturbances in the structure and dynamics of Pinus hartwegii. This specie is located towards the upper limits of the altitudinal gradient (3500 - 4100 masl) constituting the only pine species in the world capable to be established in those extreme environmental conditions. The information was collected through the implementation of 30 Sampling Plots (SP) of $20 \times 50 \mathrm{mts}\left(1000 \mathrm{~m}^{2}\right)$ in three forest density categories: dense, semi-dense and fragmented. For each forest category, all trees $\geq 2.5 \mathrm{~cm}$ DBH were measured in $10 \mathrm{SPs}$. The measurement variables were DBH, total and commercial height, forest health and forest extraction. The results show the abundance of dense, semi-dense and fragmented forest (336, 202 and 150 trees $/ \mathrm{Ha}^{-1}$ ), with extraction percentages of $11 \%, 20 \%$ and $33 \%$ respectively. The horizontal structure distribution shows the shape of an inverted $\mathrm{J}$ for the three conditions. However, the phytosanitary conditions of the semi-dense forests $(83 \%$ infested trees) and fragmented $(63 \%$ infested trees), do not guaranties the survival of the adult trees, implying an intensification of the fragmentation process for the next decade; given the reduction of the regeneration patterns due to the lack of healthy tree breeding.
\end{abstract}

Keywords: High-Mountain Forests; Fragmentation; Forest Structure; Forest Health

\section{Introduction}

Worldwide, high-mountain forests represent one of the main sources of local and regional environmental services. Besides, they are important habitats of an extensive rank of endemic species associated; nevertheless, are also environments threatened by over-exploitation and practices of land management. Paradoxically, the deterioration of the high-mountain forests is characterized by its scarcity of data and lack of empirical analyses.

In the case of Mexico, high-mountain forests are intimately related to the provision of environmental services that fulfil the needs of the largest urban conglomeration in Latin America. Mexico City and its metropolitan area depend directly of the environmental services provided the only zone of high-mountain forests in the country, the transversal volcanic system. The transversal volcanic system includes three of the highest volcanic buildings of the country: Popocatépetl, Iztaccihuatl and the Nevado de Toluca.

The forest coverage also has been reduced progres-

*Corresponding author. sively, originating social, economic, and ecological problems. Among the most pressing degradation factors it is possible to mention the lack of forest planning, disturbances in the wildfire regime, overgrazing and atmospheric pollution [1].

Deforestation is usually the most utilized indicator to measure forest depletion [2]. Nevertheless, other evidence of deterioration is the trees decrease of a determined population and the reduction of species, which can be caused by natural processes such as wildfires and forest plagues, or by anthropogenic causes; mainly forest extraction [3]. These forest disturbances can modify the forest structure and its diversity [4,5]. The main conesquence is the forest fragmentation, which reduces the incorporation of new individuals to the forest [6].

Forest fragmentation is often defined as the disruption of a continuous area of forest into smaller fragments with different degrees of isolation [7]. Both deforestation and fragmentation of the native forest are urgent environmental problems due their impact on the biodiversity. According to [8], to characterize forest fragmentation, it is necessary to identify the vertical and horizontal forest 
structure.

This paper utilizes information of a case of study of the Nevado the Toluca National Park (NTNP) which is located in in the Mexican central highlands, in order to analyze the loss of the forest density as the main indicator of high-mountain forests fragmentation processes. This forest is represented by a species of pine (Pinus hartwegii), established over the altitudinal limits of the trees' communities $>4000$ masl.

The selected measurement variables were forest structure, forest health and extractive activities. The analysis of forest fragmentation presented here constitutes a contribution for improving the understanding of the processes around the high-mountain forests degradation. Furthermore, it provides important conclusions that frame the future implications on the forest management, its resources and the provision of strategic environmental services such as drinking water supply to large metropolises.

\section{Materials and Methods}

\subsection{Description of the Case Study}

The NTNP is located in the State of Mexico and covers approximately 51,000 has (Figure 1) around the $\mathrm{Xi}$ nantécatl volcano (GEM, 1999), which belongs to the transversal volcanic system. Its forests are dominated by species of conifers (Pinus spp and Abies religious) and, in smaller proportion by broad-leaf species (Quercus spp and Alnus jorullensis) (Figure 2). However, the reduc- tion of the arboreal density, illegal logging and the problems of forest health affect mainly the forests of Pinus hartwegii, Abies religiosa and Quercus laurel [9].

\subsection{Pine Forest}

Given their diversity, this study focuses on pine forests. In the case study there are three dominant pine species: at an altitude of $<3000 \mathrm{msnm}$ the species found are Pinus pseudostrobus; between 3000 and 3200 small fragments of Pinus montezumae can be identified. Finally, populations of Pinus hartwegii dominate the upper limits of the trees' communities (3500 to 4100 masl). This altitudinal range concentrate dense forests (Figure 3), therefore, the population of Pinus hartwegii is constituted as one of the species located at greater altitude ranges worldwide [9].

\subsection{Sampling}

The sampling was carried out in the forest of Pinus hartwegii, being the only arboreal species adapted to conditions of high altitude, establishing up to the 4390 masl in the study area. The sampling method was first based on secondary data, where the utilization of geographical information systems (GIS) permitted the localization of the Sampling Plots (SP). The pine forest density loss for the period 1972-2000 (Franco et al., 2006) was considered as the main disturbance variable. Hence, three Pinus hartwegii populations were identified (dense, semi-dense and fragmented) around the Xinantécatl volcano (Figure 4).

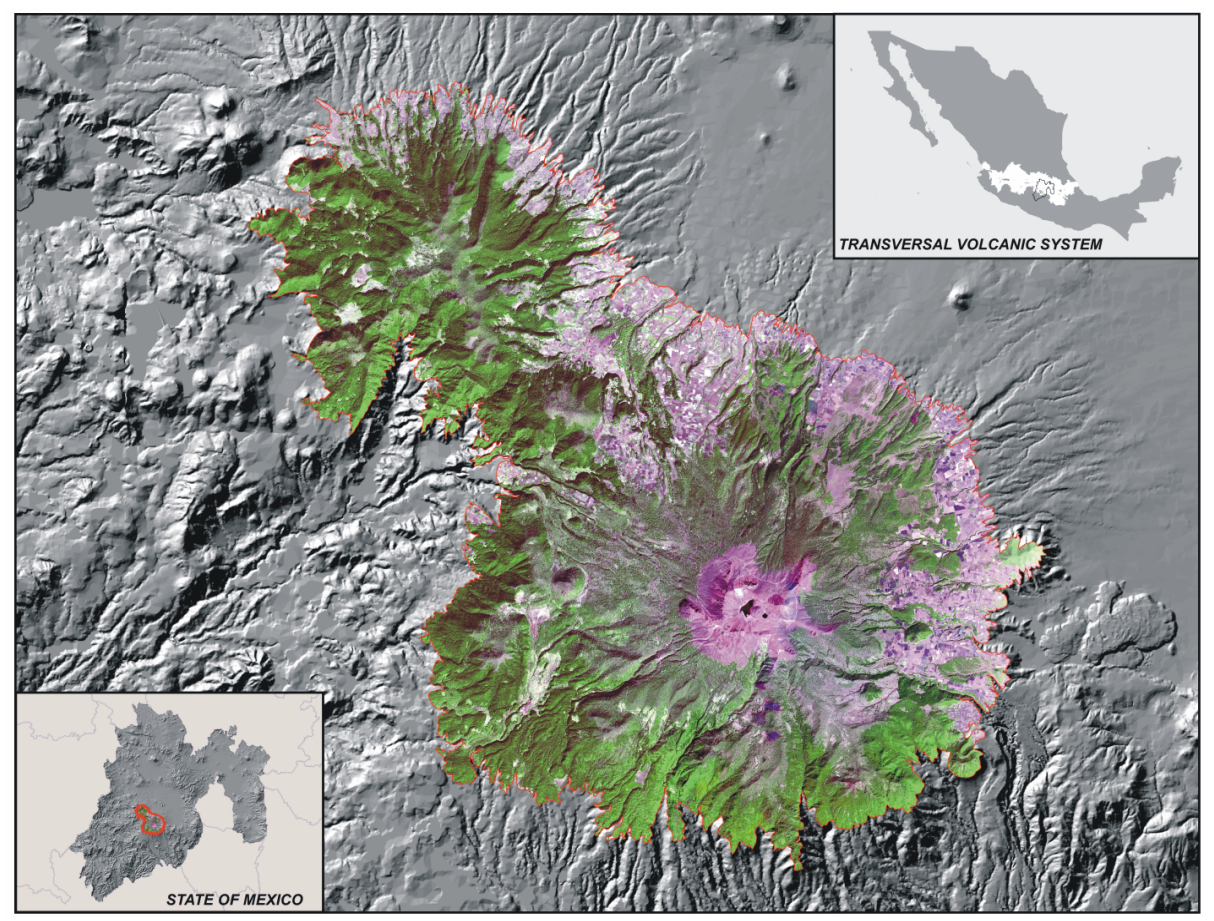

Figure 1. Nevado de toluca national park (NTNP). 


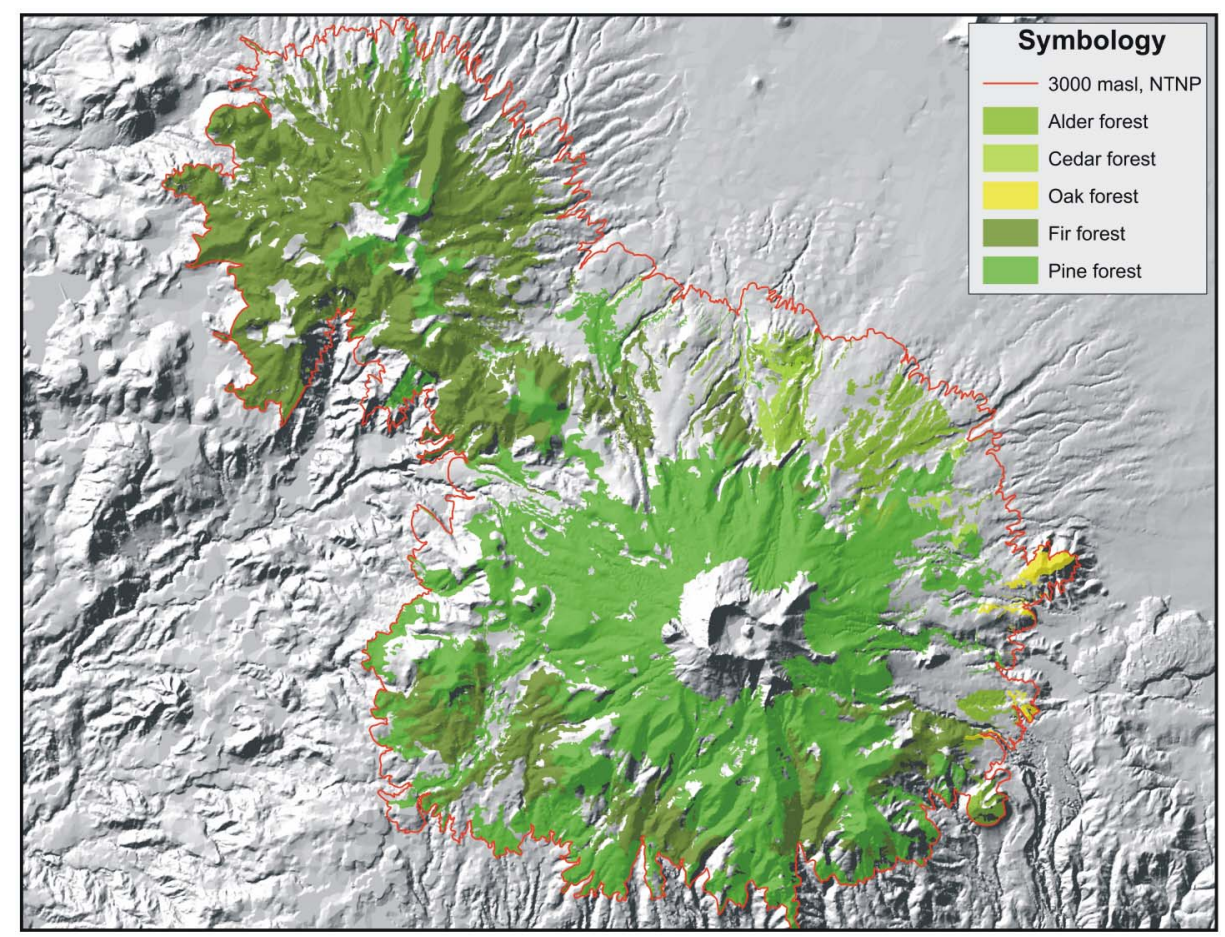

Figure 2. Nevado de toluca national park forests.

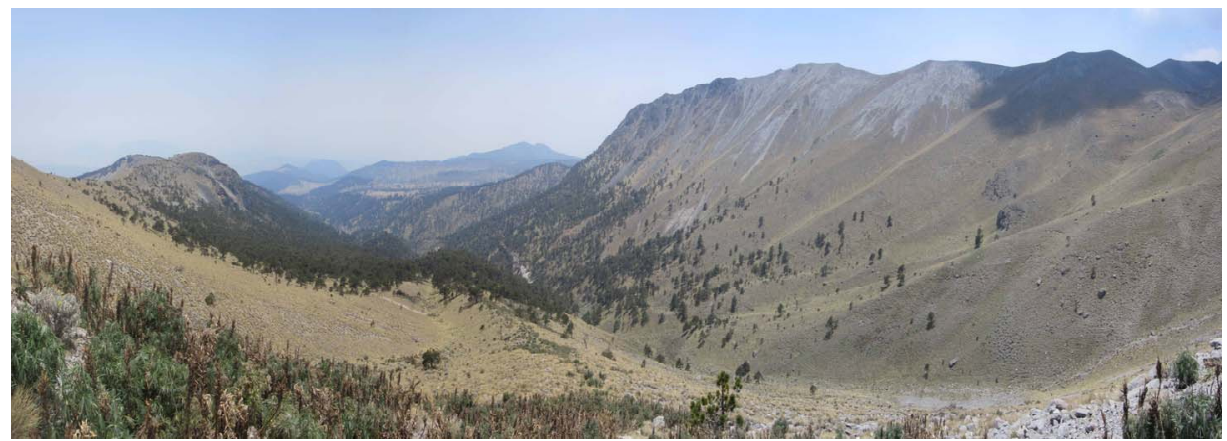

Figure 3. Pinus hartwegii forest (4100 masl), NTNP.

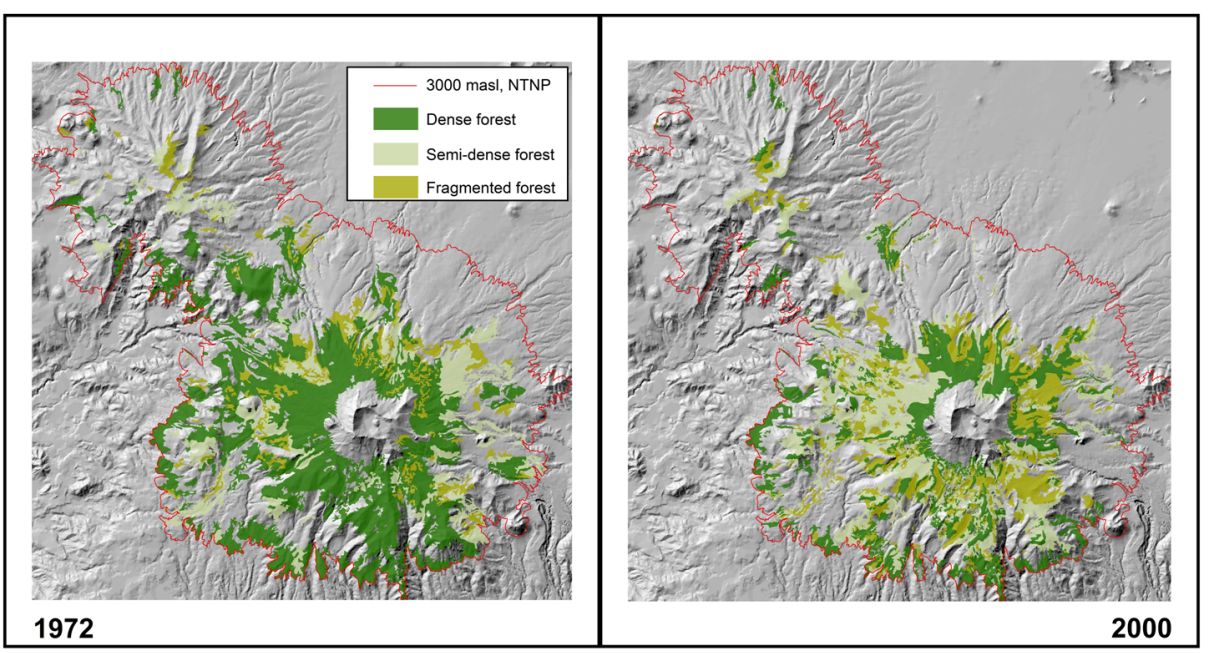

Figure 4. Pine forest density reduction 1972-2000. 
The comparison of the two periods shown in Figure 4 represents the evidence of dense pine forest reduction in more than $40 \%$ of its surface [10]. As a result of this information 10 SPs of $20 \mathrm{~m} \times 50 \mathrm{~m}$ were defined for each forest condition (dense, semi-dense and fragmented). The SPs were established by a stratified random sampling (Figure 5). In each SPs, individuals older or equal to 2.5 $\mathrm{cm}$ of Diameter at Breast Height (DBH) were measured, following the criteria proposed by $[9,11]$.

\subsection{Measurement Variables}

The variables DBH, total and commercial height, and forest health were measured. These variables gave the characterization of the vertical and horizontal structure, as well as the phytosanitary condition of dense, semidense and fragmented forests. In addition, the basal diameter of the extracted trees was measured in each SP in order to characterize the effect of forest extraction.

The distribution of the number of individuals by diametric category was compared among the dense, semidense and fragmented forests through a one-way variance analysis with a significance level of $\mathrm{p}<0.05$. The relation height-diameter was determined through a polynomial regression model. This analysis helped to compare the adjustment curves for each condition with a level of significance of $\mathrm{p}<0.05$.

The presence of forest plagues was used as an indica- tor regarding forest health. The presence of bark beetle (Dendroctonus adjunctus) was characterized by using the method proposed by [12], while the incidence of dwarf mistletoe (Arceuthobium globosum and A. Vaginatum) was characterized by utilizing the method proposed by [13].

\section{Results}

\section{Description of the High-Mountain Forest}

This study defines high-mountain forests in Mexico as the forest ecosystem developed above the 3500 masl. This characterization follows the establishment of Pinus hartwegii populations such as the only species capable to adapt to cold and extreme altitude conditions.

The structural characteristics of the high-mountain forests are particularly associated with a specific range of human activities. Aspects of the extractive activities of high-mountain forests in the case study selected include fuelwood collection and the extraction of timber [9]. Even though the forests are located above the superior limits of communities and crop fields, they are in severe pressure due to anthropic activities, leading to a local fragmentation of the pine forest. Forest fragmentation is associated to overgrazing, wildfire, and extraction of infested trees.

For the comparison of the horizontal structure among

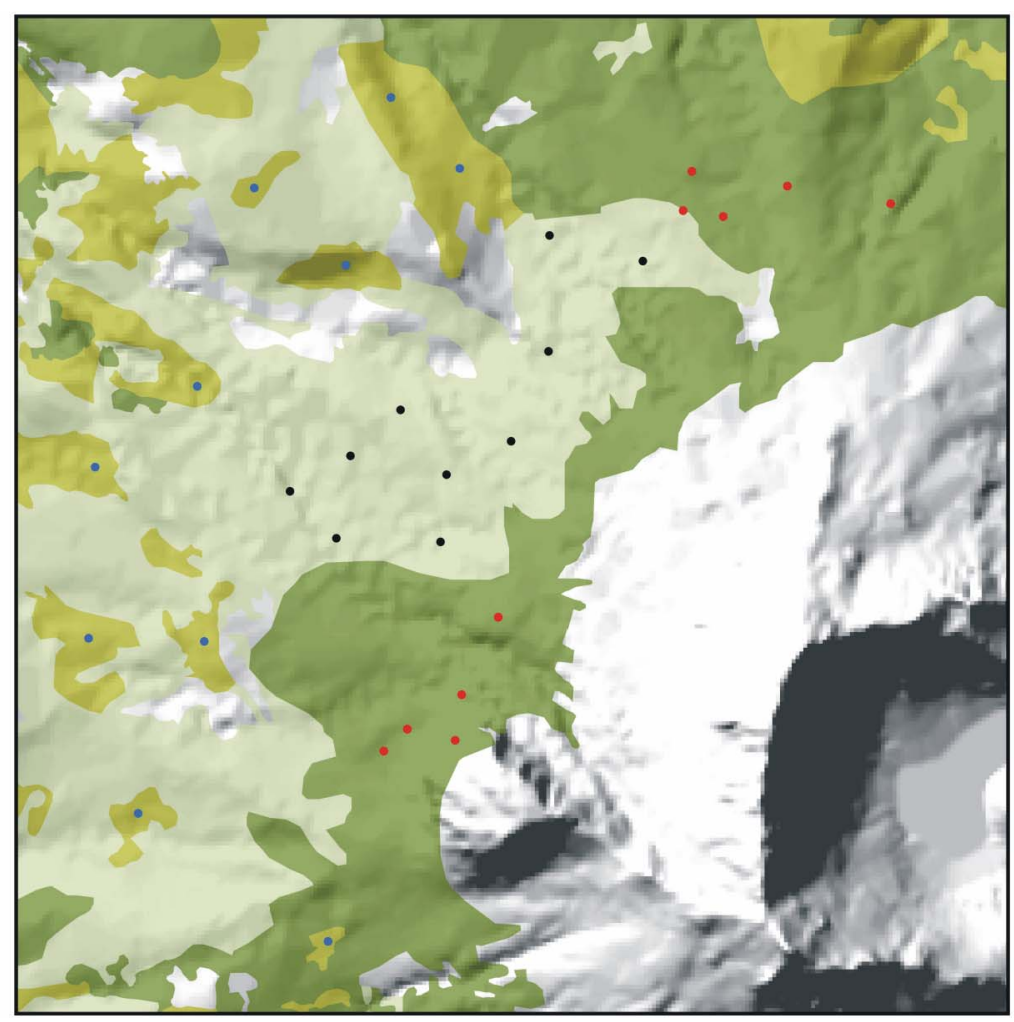

Symbology

Forest

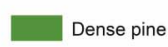

Semi-dense pine

Fragmented pine

Sampling plots

- Dense

- Semi-dense

- Fragmented

$20 \mathrm{~m} \times 50 \mathrm{~m}$

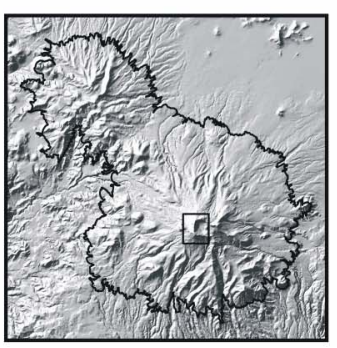

Figure 5. Sampling method. 
the three forest conditions, the individuals were classified by diametric category. The results show significant differences $(p<0.05)$ in the six first classes, where the dense forest presents greater quantity of individuals with regard to the other two conditions (Figure 6). This suggests that the extraction of trees with smaller diameters is favoring the fragmentation of pine forest. The extraction of these trees in the study area is related to the comercialization of firewood [9].

The decline curves of the relation diameter-height among the three forest conditions are adjusted to a second-degree polynomial decline of the dense and semidense forest, while the fragmented forest presents a thirddegree decline (Figure 7). Such curves do not show significant differences $(p>0.05)$; this suggests that the relation height-diameter is not seen affected by the forest fragmentation. Nevertheless, the upper stratum of the fragmented forests reaches a height of 35 meters, five more than the dense and semi-dense pine forests. This trend in the fragmented forest is related to an increase in the light, space and nutrients availability.

Dense forest presents an abundance of 336 trees/ha. The forest phytosanitary condition and its extraction patterns are closely related. For the case of the dense forest and, despite existing an extraction of 11\% (43 trees) distributed in all the diametric categories, this does not mean an increase in the attack of forest plagues (Figure 8). It is important to mention that the accessibility to dense forest is more difficult, given the abrupt slopes in which it is developed. Therefore, the roads network this zone is very precarious. For this reason, dense forest does not present problems of forest health, since only the $1 \%$ has some degree of attack by bark beetle (Dendroctonus adjunctus), the main plague of the high-altitude pine forests in Mexico.

However, the semi-dense forest presents an abundance of 202 trees/ha and an extraction of 20\% (51 trees), mainly distributed between the 20 and $55 \mathrm{~cm}$ of diametric class (Figure 9). As opposed to dense forests, the extraction of semi-dense pine forest is concentrated on large diameters, what implies a greater damage on residual woodland. Furthermore, this indicates that the population of semi-dense forest is vulnerable to the attack of plagues and parasitic plants, being Dendroctonus adjunctus the plague with greater presence. This situation allows for a continuous pine forest fragmentation, and denotes the need for health logging actions for forest plagues control.

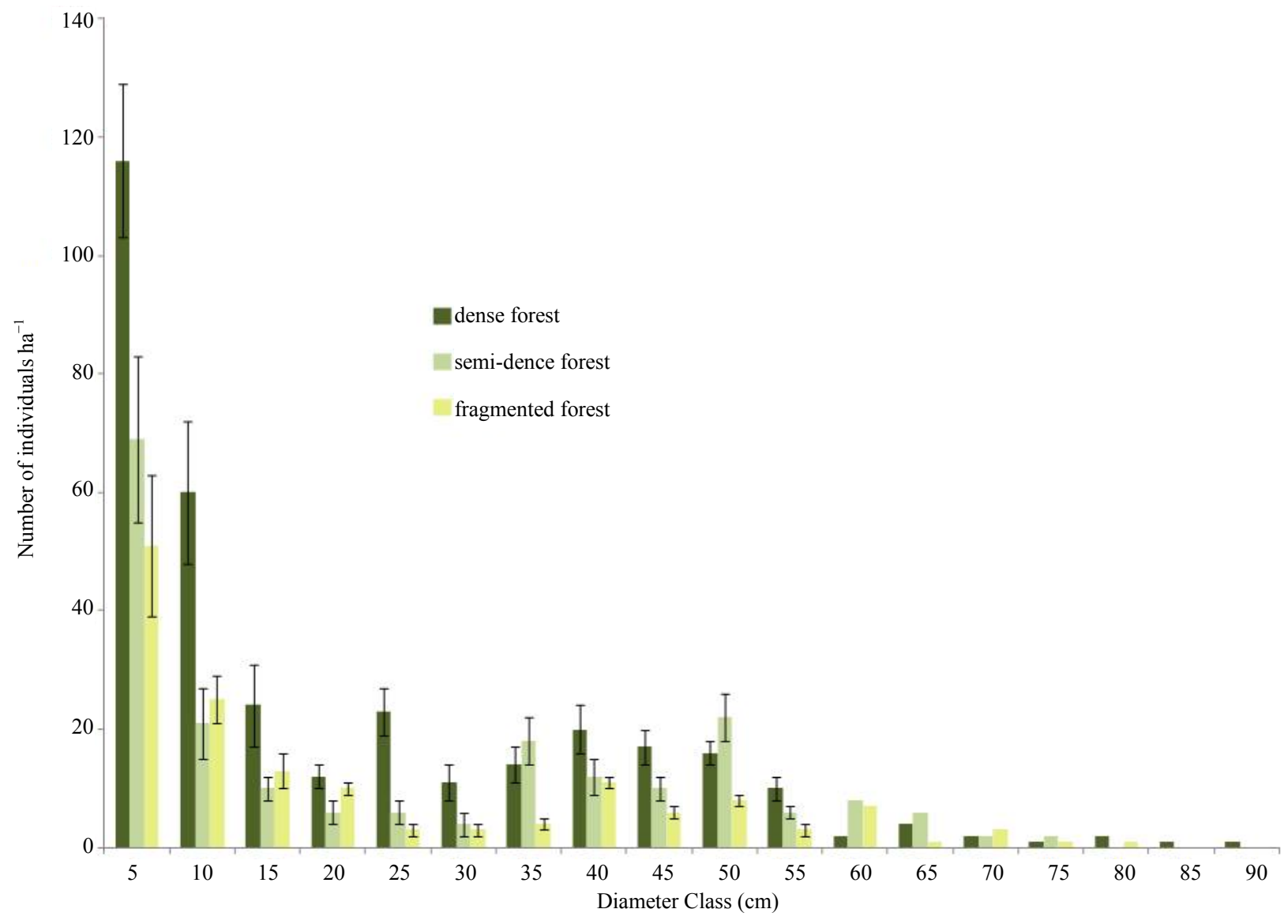

Figure 6. Horizontal structure of Pinus hartwegii forest in the NTNP. 


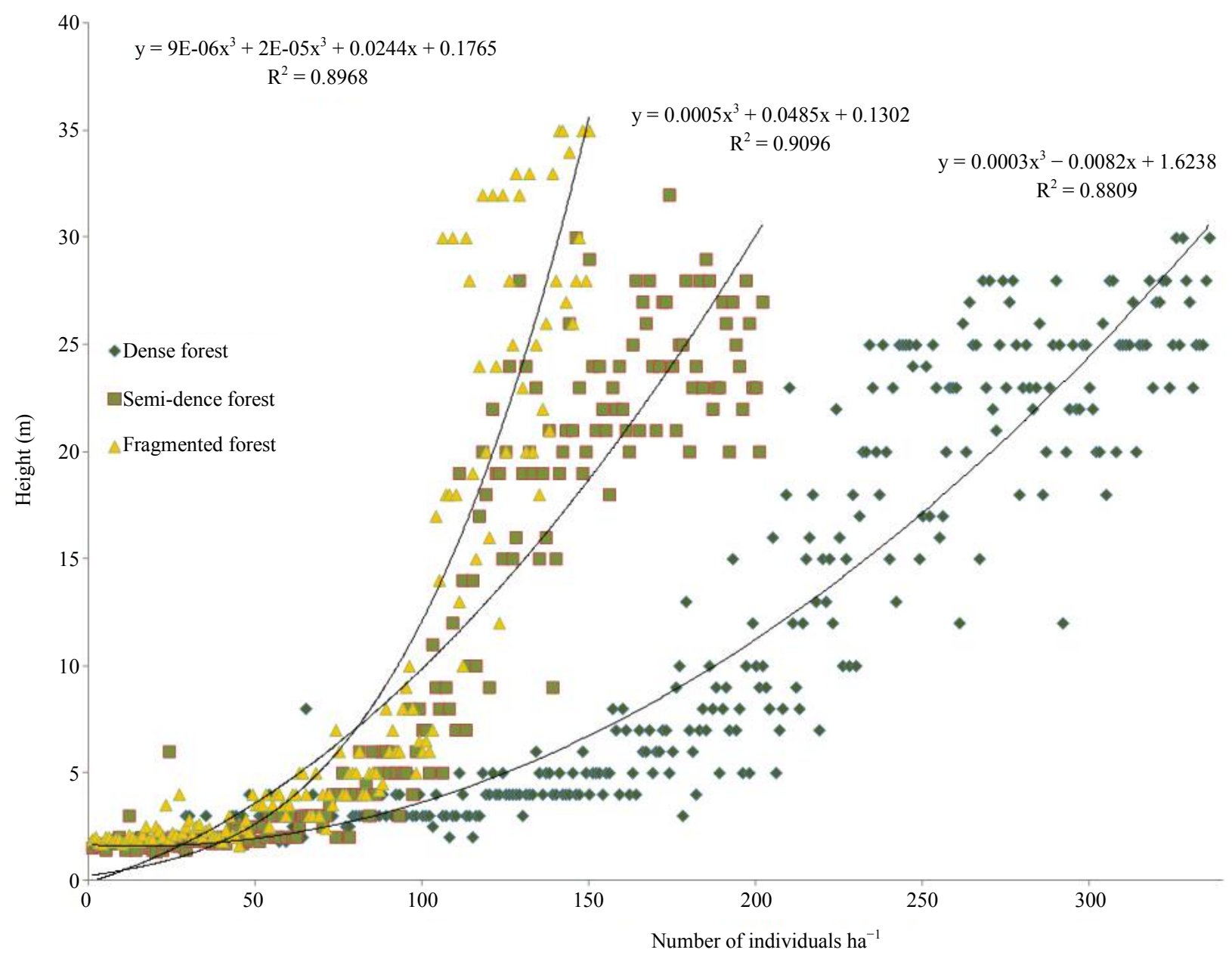

Figure 7. Height-diameter relation between dense, semi-dense and fragmented forest.
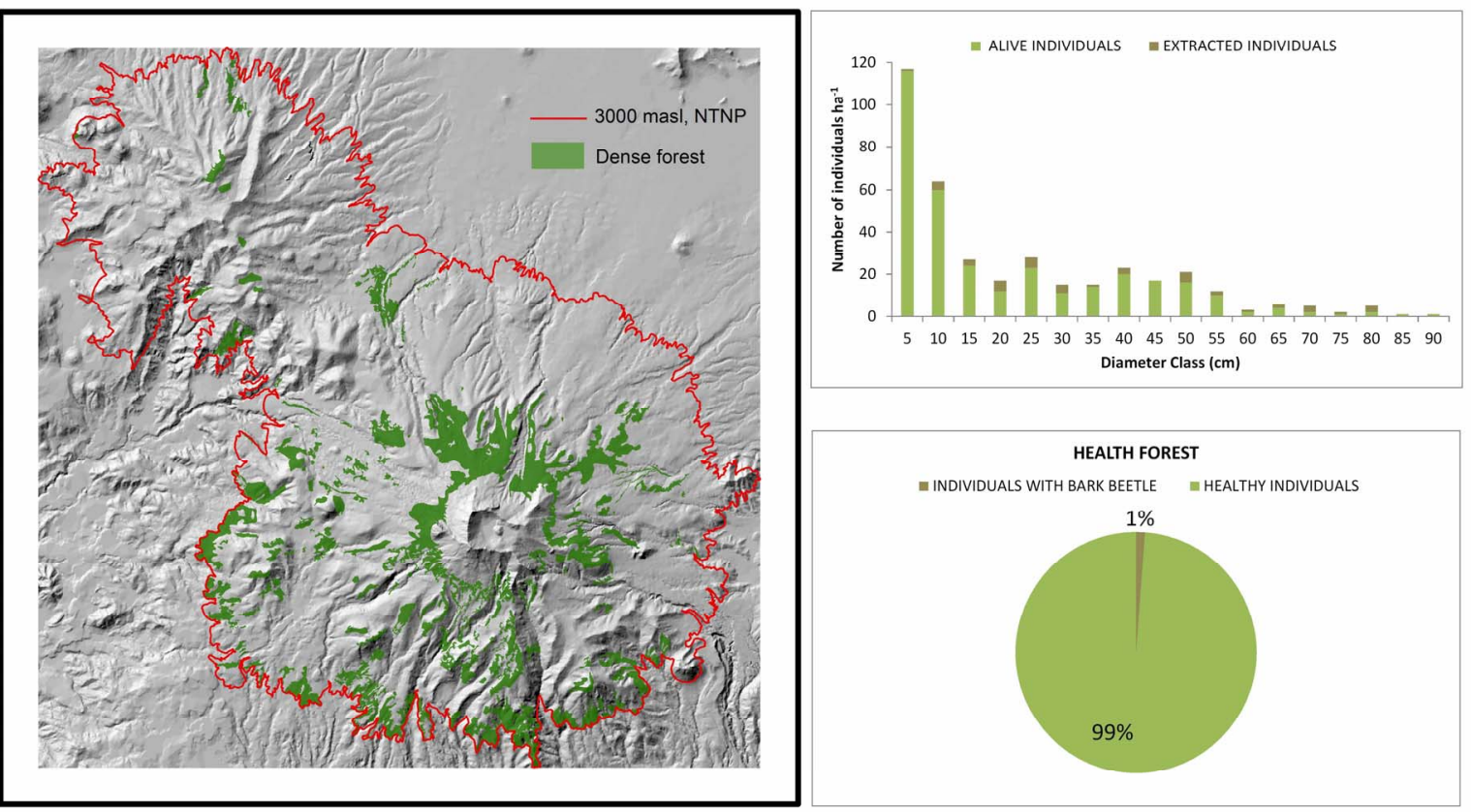

Figure 8. Extraction and forest health in dense forest. 


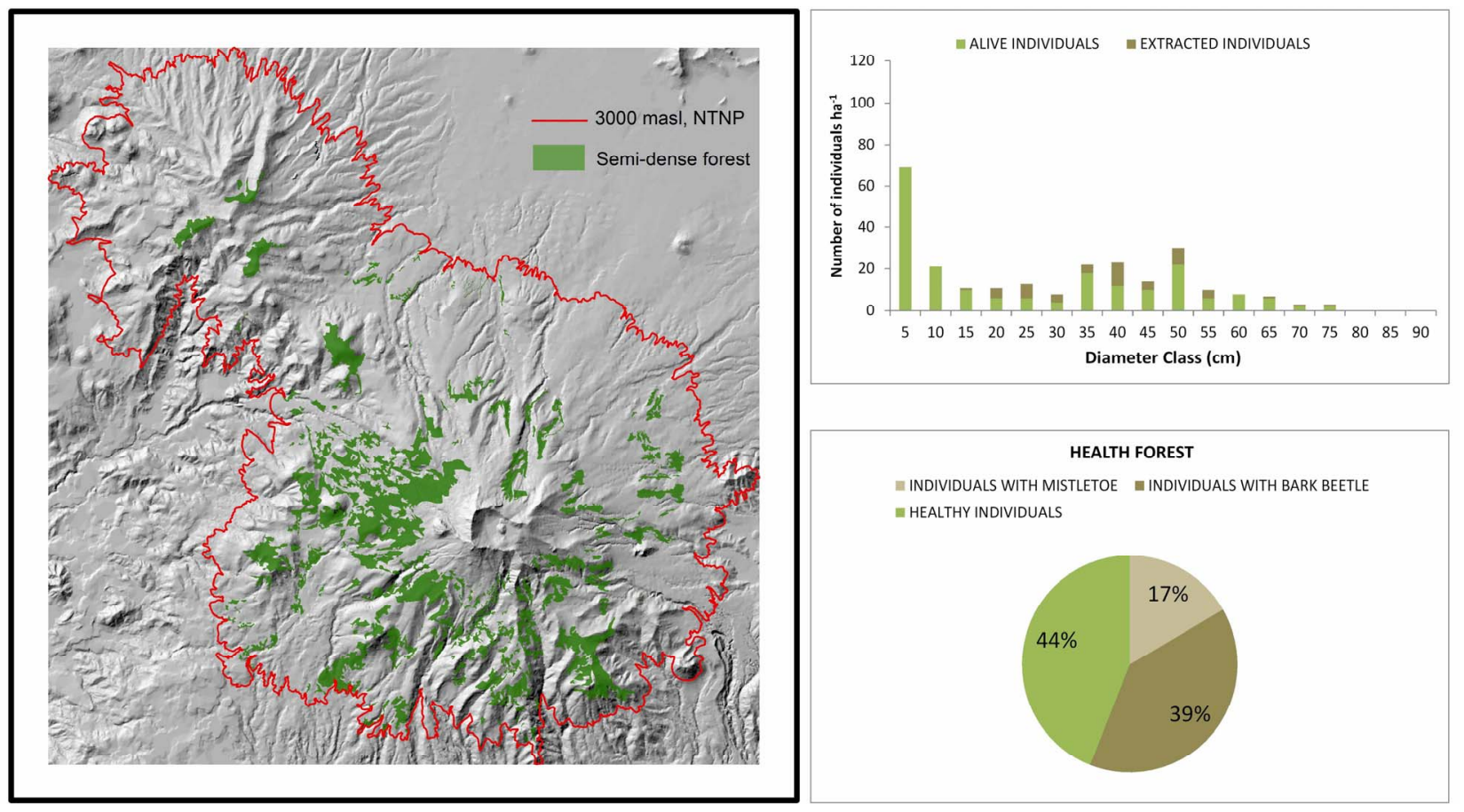

Figure 9. Extraction and forest health in semi-dense forest.
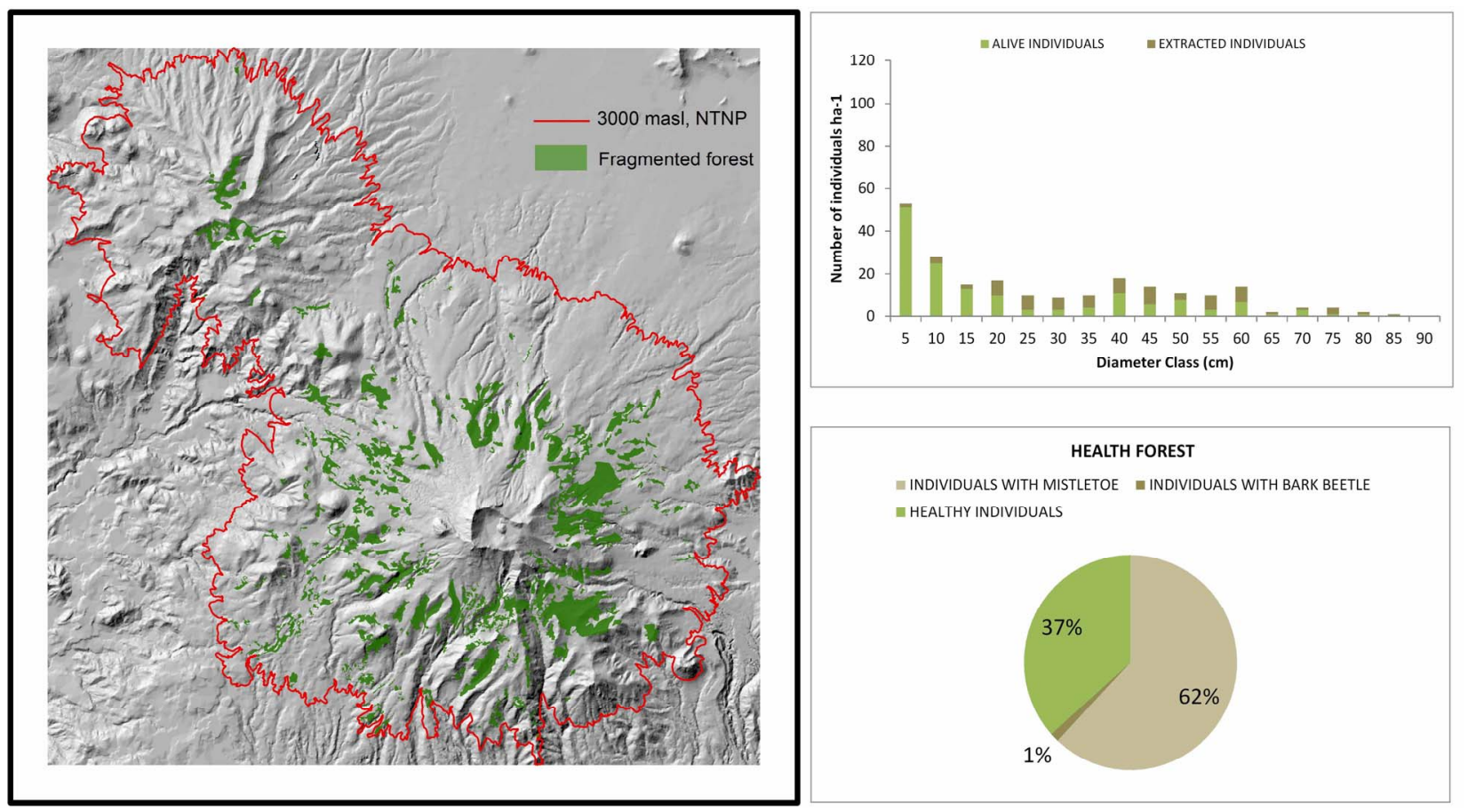

Figure 10. Extraction and forest health in fragmented forest.

The fragmented forest presents an abundance of 150 trees/ha and an extraction of 33\% (73 trees), distributed in all the diametric classes, however, accentuated between the 20 and $60 \mathrm{~cm}$ of diametric class. This implies a greater damage on the residual woodland that is translated into an increase of the incidence of parasitic plants
(Arceuthobium globosum and A. vaginatum). 37\% of healthy woodland does not guarantee the survival of fragmented forest, condition by which it is expected a land use change from woodland to grassland (Figure 10). This situation represents a dramatic reduction in forest surface and consequently, a depletion of the environ- 
mental services required for central Mexico.

\section{Conclusions}

The pine forest fragmentation in the NTTP is similar to other Natural Protected Areas in the centre of Mexico. The empirical information provided by this paper illustrates that high-mountain forests have a notorious trend to fragmentation. This process is closely related to extractive activities, forest plagues, and wildfires.

The forest structure explained through the distribution of trees abundance by diametric category shows an inverted J. This evidence suggests that the analysed forest is in an apparently good conservation stage. However, the main problem is the phytosanitary condition of the trees, since bark beetle and dwarf mistletoes attack the $83 \%$ of individuals in the semi-dense forest and the $63 \%$ of individuals in fragmented forest.

These problems describes the high perturbation levels of the high-mountain forests, and furthermore, their scarce possibilities of natural regeneration. Problems accentuated by the lack of healthy tree breeding and immoderate processes of forest extraction. This trend implies to the short term, high-mountain forests will suffer a land use change, from dense forests to fragmented forests, and from fragmented forests into grasslands. As a consequence, a reduction in the provision of environmental services is expected; particularly water supply for metropolitan areas.

One of the factors that favour the fragmentation process in high-mountain forests is the restriction to forest management. In the case study it is not possible to carry out actions to favor forest growth and regeneration. For this reason, it is necessary to delegate forest management to local communities [14]. Furthermore, modifying the current forest management policies in natural protected areas is required, especially regarding the areas with important human settlements, such as central Mexico. For this case, forest management prohibition is not a conservation option anymore, becoming a cause for the continuous fragmentation of high-mountain forest.

\section{REFERENCES}

[1] J. A. Encina, F. J. Encina, E. Matarocha and J. I. Valdez, "Aspectos Estructurales, Composición Florística y Caracterización Ecológica del Bosque de Oyamel de la Sierra de Zapalinamé, Coahuila, México," Boletín del a Sociedad Botánica de México, Vol. 83, 2008, pp. 13-24.

[2] Y. Vázquez, and S. A. Orozco, "La Destrucción de la
Naturaleza," Fondo de Cultura Económica, México, 1989.

[3] L. Villers-Ruiz, L. García del Valle and J. López-Blanco, "Evaluación de los Bosques Templados en México: Una Aplicación en el Parque Nacional Nevado de Toluca," Investigaciones Geográficas, Vol. 36, 1998, pp. 7-21.

[4] J. Hitimana, J. L. Kiyiapi and J. T. Njunge, "Forest Structure Characteristics in Disturbed and Undisturbed Sites of Mt. Elgon Moist Lower Montane Forest, Western Kenya," Forest Ecology and Management, Vol. 194, No. 1-3, 2004, pp. 269-291. doi:10.1016/j.foreco.2004.02.025

[5] C. Cannon, D. R. Peart and M. Leighton, "Tree Species Diversity on Commercially Logged Bornean Rainforest," Science, Vol. 281, No. 5381, 1998, pp. 1366-1368. doi:10.1126/science.281.5381.1366

[6] W. Laurance, H. Nascimento, S. G. Laurance, A. C. Andrade, P. M. Fearnside, J. E. L. Ribeiro and R. L. Capretz, "Rain Forest Fragmentation and the Proliferation of Successional Trees," Ecology, Vol. 87, No. 2, 2006, pp. 469-482. doi:10.1890/05-0064

[7] R. Bustamante, J. A. Simoneti, A. A. Grez and J. San Martín, "Fragmentación y Dinámica de Regeneración del Bosque Maulino: Diagnostico Actual y Perspectivas Futuras," 2005, pp. 529-539.

[8] M. Wulder, J. C. White, M. E. Andrew, N. E. Seitz and N. C. Coops, "Forest Fragmentation, Structure, and Age Characteristics a Legacy of Forest Management," Forest Ecology and Management, Vol. 258, No. 9, 2009, pp. 1938-1949. doi:10.1016/j.foreco.2009.07.041

[9] A. Endara, S. Franco, G. Nava, J. I. Valdez and T. Fredericksen, "Effect of Human Disturbance on the Structure and Regeneration of Forests in the Nevado de Toluca National Park, Mexico," Journal of Forestry Research, Vol. 1, No. 23, 2012, pp. 39-44.

[10] S. Franco, H. H. Regil and J. A. B. Ordoñez, "Dinámica de Perturbación-Recuperación de las Zonas Forestales en el Parque Nacional Nevado de Toluca," Madera y Bosques, Vol. 1, No. 12, 2006, pp. 17-28.

[11] E. Villavicencio and J. I. Valdez, "Análisis de la Estructura Arbórea del Sistema Agroforestal Rusticano de Café en San Miguel, Veracruz, México," Agrociencia, Vol. 4, No. 37, 2003, pp. 413-423.

[12] S. Clarke and R. F. Billings, "Analysis of the Southern Pine Beetle Suppression Program on the National Forests in Texas in the 1990s," Journal of Forestry, Vol. 2, No. 27, 1990, pp. 122-129.

[13] F. Hawksworth, "Taxonomía y Distribución de Arceuthobium en México y Centroamérica," Instituto Nacional de Investigaciones Forestales y Agropecuarias, No. 60, 1991, pp. 559-591.

[14] D. Barton and L. Merino, "La Experiencia de las Comunidades Forestales en México. 25 Años de Silvicultura y Construcción de Empresas Forestales Comunitarias,” Instituto Nacional de Ecología, 2004. 